\title{
Indigenous Peoples and climate-induced relocation in Latin America and the Caribbean: managed retreat as a tool or a threat?
}

\author{
Beatriz Felipe Pérez ${ }^{1}$ (i) $\cdot$ Alexandra Tomaselli ${ }^{2}$ (i)
}

Accepted: 22 April 2021 / Published online: 29 July 2021

(C) AESS 2021

\begin{abstract}
Climate-induced relocation is expected to become an adaptive response for one sector of the society that is otherwise already in a vulnerable situation and often living in remote areas, that is, Indigenous Peoples. Several Latin American countries have referred to planned relocation or managed retreat as one of their adaptation strategies within their Nationally Determined Contributions to the United Nations Framework Convention on Climate Change. However, a gap in academic analysis exists regarding not only the potential impacts but also the consequences of climate-induced planned relocations both in the broader context of Latin America and in the specific case of Indigenous Peoples living in that region. In addition, academia has so far underexplored the adverse impacts of managed retreat on Indigenous Peoples, such as the loss of a sense of community, culture, and traditional knowledge. Against this background, this article offers an overview on two key cases of climate-induced (planned) relocation of Indigenous Peoples in Latin America and the Caribbean (the Gunayala people in the San Blás archipelago in Panama and the case of the densely Indigenous-inhabited Mexican state of Chiapas), explores whether managed retreat has been or may become a tool or a threat, and provides a list of specific policy recommendations to be taken into consideration in similar cases.
\end{abstract}

Keywords Climate change $\cdot$ Indigenous Peoples $\cdot$ Planned relocation $\cdot$ Managed retreat $\cdot$ Gunayala $\cdot$ Chiapas

\section{Introduction}

In these uncertain times, and along with the coronavirus disease 2019 (COVID-19) pandemic, climate change continues to represent one of the greatest societal challenges we must all face and tackle in the upcoming decades. The consequences of rising atmospheric temperatures due to human activities continue to alter the global climate system. Droughts, floods, sea level rise, and other climate change adverse effects, in combination with socioeconomic inequalities and internal and international conflicts, are increasingly intermingled with human mobility (IPCC 2014; Miletto et al. 2017; IPCC 2018; 2019). In 2019,

For consideration to be published in the Special issue, "Managed Retreat and Environmental Justice in a Changing Climate" is edited by A.R. Siders and Idowu (Jola) Ajibade.

Beatriz Felipe Pérez

beatriz.felipeperez@gmail.com

1 Tarragona Centre for Environmental Law Studies (CEDAT-URV), Rovira i Virgili University, Tarragona, Spain

2 Institute for Minority Rights (IMR), Eurac Research, Bolzano-Bozen, Italy nearly 24.9 million new displacements were related to disasters (although not all of them were connected to climate change) (IDMC 2020). However, the more the impacts of climate change intensify, the more the people will be affected (IOM 2009).

After many years of invisibility, "climate change-induced human mobility" is finally receiving increased attention in the legislative and policy spheres. However, climate-induced

\footnotetext{
${ }^{1}$ Although the debate on the terminology related to these issues remains unsettled, in this article "climate change-induced human mobility" is used as a synonym for the working definition of "climate migration" provided by the International Organization for Migration (IOM 2019a). The term "climate migration" encompasses different types of movements in the context of climate change. The terms climate-induced relocation, managed retreat, and planned relocation are used interchangeably in this policy analysis. Climateinduced relocation can be understood as a subcategory of "climate migration." There are also several typologies of climate-induced relocation. For instance, (1) those who need to be relocated from areas prone to sudden-onset disasters; (2) those whose livelihoods are threatened by slow-onset effects of climate change; and (3) those whose country or parts of their country face destruction from the effects of climate change (e.g., small island states) (Ferris 2012). Planned relocation in the context of climate change is defined as "a planned process in which persons or groups of persons move or are assisted to move away from their homes or place of temporary residence, are settled in a new location, and provided with the conditions for rebuilding their lives" (IOM 2019b, 157). It can be temporary or permanent and either forced or voluntary (Ferris 2012).
} 
relocation has received much less international attention than other climate change-induced mobility scenarios (Ferris 2014). Evidence that the impacts of climate change are becoming more severe indicates that managed retreat programs will be increasingly necessary in the coming decades (Siders et al., 2019; Carey 2020). Due to this foreseen necessity, the 2018 Global Compact for Safe, Orderly and Regular Migration includes among its actions for enhancing availability and flexibility of climate-induced regular migration, "devising planned relocation [...] in cases where adaptation in or return to their country of origin is not possible" (Objective 5, paragraph 21, h).

Since the adoption of the 2010 Cancun Agreements as part of the United Nations Framework Convention on Climate Change (UNFCCC) Adaptation Framework, "planned relocation" has been officially recognized as a possible adaptation action, and states are invited to put in place action on measures to enhance understanding, coordination, and cooperation with regard to it (Cancun Agreements paragraph 14f). In addition, the Warsaw International Mechanism for Loss and Damage associated with Climate Change Impacts was established at the UNFCCC Conference of the Parties (COP) 19 in 2013. The Warsaw International Mechanism is guided by the Executive Committee (WIM Excom) which includes the Task Force on Displacement, created two years later at COP21. This task force aims to develop an integrated approach to prevent, minimize, and address displacements (including planned relocation) related to the adverse impacts of climate change UNFCCC (2015).

Another action that deserves attention is the Nansen Initiative on Disaster-Induced Cross-Border Displacement, which was finalized in 2015 with the adoption of the Agenda for the Protection of Cross-Border Displaced Persons in the Context of Disasters and Climate Change (hereinafter, the Protection Agenda). The 109 ratifying states of the Protection Agenda are thus bound to continue supporting the work of the Platform on Disaster Displacement as well as to implement the recommendations of such Agenda, which includes several provisions related to planned relocation. In addition, the Nansen Principles include a series of purposes related to climate displacement (including planned relocation) which shall be applied by the governments and regional organizations Nansen Intitiative (n.d.).

Indigenous Peoples ${ }^{2}$ are among those sectors of society who are more exposed than others to the adverse effects of climate change. At the same time, they are primary actors in terms of both adaptation and mitigation (Macchi 2008;

\footnotetext{
2 The term Indigenous People or Peoples is employed with regard to those peoples who self-identify as such in accordance with Art. 1.2 of the International Labour Organization Convention No.169 concerning Indigenous and Tribal Peoples in Independent Countries of 1989 (ILO C169) and Art. 33.2 of the United Nations Declaration on the Rights of Indigenous Peoples (UNDRIP) of 2007.
}

Hansungule and Oluborode Jegede 2014). Indeed, the majority of Indigenous Peoples tend to have a spiritual relationship not only with the(ir) traditional or ancestral land. ${ }^{3}$ For those peoples who live on traditionally owned or otherwise traditionally used land, such use and access to these territories provide a way to secure their livelihoods, their culture, and therefore their lifestyle (or way of life) (Tomaselli 2017a). At the same time, Indigenous Peoples, who represent approximately $6 \%$ of the world population (i.e., 370 million individuals according to UN estimates), continue to belong to the poorest sectors and live at the fringes of society. This makes them particularly vulnerable to disasters and natural hazards and, thus, to climate change-induced human mobility (Sardiza Miranda et al. 2020). ${ }^{4}$

Although the Global North is responsible for most of the past greenhouse gas emissions, the adverse impacts of climate change are hitting the Global South harder (González 2015). Climate-induced (planned or not) relocation is thus widely expected to become an adaptive response especially for those sectors of the society that are already in a vulnerable situation and often living in remote areas or in urban suburbs, that is, Indigenous Peoples (Dannenberg et al. 2019; Carey 2020). In this sense, climate migration (and managed retreat), especially when Indigenous Peoples are involved, can become a clear case of climate and environmental injustice (González 2015; González 2021).

A research gap exists regarding not only the potential impacts but also the consequences of planned relocation both in the broader context of Latin America and in the specific case of Indigenous Peoples living in that region. In addition, academia has so far underexplored the adverse impacts of planned relocation on Indigenous Peoples, such as the loss of a sense of community, culture, and traditional knowledge or other health and gender impacts and economic decline.

This is the tenuous situation in which most of the inhabitants of the more than 300 low-lying coral islands of the archipelago on the Caribbean coast of Panama, home of the Gunayala Indigenous Peoples, have found themselves. Due to extreme weather-related events, sea level rise, overpopulation, and other factors, the inhabitants of one of the most densely populated islands (Gardi Sugdub) decided to relocate to the mainland in 2010 (Displacement Solutions 2016). After nearly 10 years, this relocation process remains mostly

\footnotetext{
${ }^{3}$ In the Latin American context, Indigenous Peoples often refer to the(ir) land also as "Mother Earth" (in Spanish: Pachamama).

${ }^{4}$ Indigenous Peoples (as well as other sectors of the society) have been continuously migrating both internally and transnationally due to several socioeconomic hurdles all over Latin America (as well as in other parts of the world). Indeed, the majority of Indigenous Peoples worldwide currently live in urban contexts also as a result of such migration flows (Stephens 2015). On Indigenous migrants in Latin America, see, e.g., Robson (2019) and VelascoOrtiz (2014) with regard to Indigenous transnational migration from Mexico to USA, and Ødegaard (2016) on Indigenous migrants within and from Peru.
} 
unfinished and the impacts on the living conditions of the Gunayala remain unexplored.

Another significant case is that of the (somewhat-planned) relocation that took place in Chiapas, Mexico, as a consequence of the devastating effects of Hurricane Stan in 2005, which left 92,000 people (mainly Indigenous) displaced (Zapata Martí 2006, 22; Escobedo D’Anglés 2015, 362; Díaz-Leal 2017, 88). After 16 years, the new settlements are far from being completed or fully working, and a number of infrastructural as well as socioeconomic and cultural problems persist but have received little political and academic attention.

Against this background, this policy analysis offers an overview on these two key cases of climate-induced relocation of Indigenous Peoples in Latin America and the Caribbean. More specifically, by exploring the case of the San Blás archipelago and the Gunayala Indigenous People and the case of the densely Indigenous-inhabited Mexican state of Chiapas, this article explores whether managed retreat has been or may become a tool or a threat for Indigenous Peoples and proposes a series of recommendations for policy makers.

\section{Methodology}

This article follows the principles of researching international environmental and human rights law, and its methodology is essentially legal. Due to the outbreak of the pandemic, it relies on secondary data provided by the (few but) top literature on this topic, and it is thus documentary in nature. However, this policy analysis's main contribution consists in the combination of the available resources on cases of (climate-induced) managed retreat in Latin America by focusing on the impacts of planned relocation of a specific vulnerable sector of the society (i.e., Indigenous Peoples) that have so far been neglected attention.

The reason why Gunayala and Chiapas climate-induced relocation processes were selected as case studies is threefold: they are among those few cases that have directly involved Indigenous Peoples; they both involve climateinduced migration related to sudden- and slow-onset weather events (i.e., sea level rise and extreme events); and both relocation processes are ongoing, having started in 2010 in Gunayala and in 2005 in Chiapas, and thus offer a retrospective analysis of these plans, which are still far from being successfully completed.

\section{Indigenous Peoples in Latin America and the Caribbean}

The subcontinent of Latin America is extremely vast, and it conventionally extends from Mexico in the North to the
Tierra del Fuego in the South, including 20 states in which Spanish or Portuguese are the official languages (that is, all states apart from Belize, French Guyana, Guyana, and Suriname). In addition, the region boasts an incommensurable geographic, demographic, and cultural richness. While the total population was estimated at more than 640 million in 2019,5 Indigenous Peoples represent $7 \%$ to $9 \%$ of the total population (i.e., between 44 and 55 million individuals). Among them, there are (at least) 826 distinct Indigenous Peoples (and, thus languages), with 200 of these living in Voluntary Isolation (Del Popolo 2017). These Peoples live in diverse environmental settings, including the coasts, the Andes and other mountainous areas, and the Amazon forest. However, today, the majority live in urban settings (Del Popolo et al. 2010).

With regard to their economic situation, Indigenous Peoples tend to remain among the poorest sectors in Latin American society (Sardiza Miranda et al. 2020). Notwithstanding the (slight) decrease of socioeconomic inequalities that the subcontinent registered at the beginning of the 2010s, the distribution of wealth remains extremely unequal (ECLAC 2016), as the 2019 protests in different countries (e.g., Bolivia, Ecuador, Chile, and Colombia) have shown. This unfair wealth allocation also occurs in those states that have a high GDP (e.g., Chile; Ministerio de Desarrollo Social y Familia 2019). The birth rate among Indigenous Peoples in this subcontinent has moderately increased in the last several decades. This increase is partially a result of more inclusive censuses, increased Indigenous participation, and profound changes at the sociopolitical level in the whole region, albeit with differences among the countries. ${ }^{6}$ However, all over the region, Indigenous Peoples continue to face many difficulties. For example, they tend to be extremely vulnerable to forced relocation due to extractivist activities, food insecurity, water scarcity or pollution, land degradation, malnutrition, and high death rates (Del Popolo 2017). In addition, they are often at the mercy of internal conflicts caused by drug trafficking, the actions of paramilitary groups, or illegal logging or other extractivist activities, which in turn have caused the murder of a number of Indigenous environmental activists (Survival International 2019; Econews Portal 2019).

\footnotetext{
${ }^{5}$ These data (that exclude the Caribbean islands) precisely amount to 644,787,000 (CEPAL 2018).

${ }^{6}$ Indeed, in comparison with the past, Indigenous Peoples are more prone to self-identify as such. However, not all censuses have included or include a question on self-identification as an Indigenous person. On these issues, see Del Popolo (2017), pp. 135 ff. and, for a retrospective, Giraudo and Sánchez (2008).
} 


\section{Climate-induced managed retreat in Latin America and the Caribbean}

Due to its socioeconomic, climate, demographic, and geographic conditions and despite having made a historically small contribution to global greenhouse gas emissions, the Latin America and Caribbean region is highly vulnerable to the impacts of climate change (ECLAC 2015). This region is already facing several serious climate change-related impacts. Inter alia, many climate change-related signals such as warming temperatures, changes in rainfall patterns, and sea level rise have been detected recently. These changes may lead to water shortages, flooding, landslides, declines in the production and quality of food, and the spread of diseases. The sectors that may be more seriously impacted by climate change are water resources and management, agriculture, plantation forestry, ecosystems, fisheries and other coastaldependent activities, and human health (IPCC 2014). It is estimated that by 2050 , the economic costs of climate change in the region may range between 1.5 and $5 \%$ of the GDP (ECLAC 2015).

In this area, these impacts are significant factors that are increasingly related to non-economic loss and damage too, such as human mobility (Priotto 2017; Thomas and Benjamin 2020). In 2019, 1.5 million new displacements were triggered by disasters in the Americas, representing $6.4 \%$ of the global total (IDMC 2020). In Mexico and Central America, drought and other extreme weather events have been contributing factors to human mobility since the late 2000 s (Warner et al. 2009). Alscher (2011) found "a linkage between environmental degradation and migration processes on both parts of Hispaniola Island" (i.e., Haiti and the Dominican Republic) (Alscher 2011, 183). In Brazil, other examples of climate-induced migration related to sudden- and slow-onset weather events (Pires et al. 2016) can be seen. In Chile, in the Monte Patria community (Limarí Province), water scarcity has affected the economy of its population, highly dependent on agriculture, and has induced the migration of large numbers of people looking for employment (Priotto 2017). Bolivia has experienced a similar situation in which the disappearance of the second largest lake in the country, Lake Poopó, induced the migration of members of the Indigenous Peoples living there, whose livelihood and rights have now been seriously threatened (Clark 2016).

Despite climate migration increasingly taking place in Latin America and the Caribbean and some countries in the Global South do have distinct policies on relocation ${ }^{7}$, to date, not many sites exist where climate-related relocation has been

\footnotetext{
${ }^{7}$ Fiji, for example, has developed policies and mechanisms to address climateinduced relocation (Republic of Fiji 2018). See Thomas and Benjamin 2018 for a comparison between the policy contexts for climate-induced migration (including planned relocation) in small islands development states in the Caribbean and the Pacific.
}

implemented (McMichael et al. 2019). In the Global South, "we know little about the policy and practice of managed retreat, other than forced displacement in the context of infrastructural development and coastal reconstruction" (Ajibade 2019, 300). In fact, in Latin America a strong tradition of development-induced displacement already exists, and most of it has been reported as a negative experience ${ }^{8}$, given the sense that "resettled communities are worse off after their resettlement" (Ferris 2012, 14).

It is widely agreed that relocation should be considered as a last resort (Barnett and Webber 2010). Even Fiji, one of the most active countries dealing with climate migration, clearly includes in its unique Planned Relocation Guidelines that "planned relocation within Fiji does represent an option of last resort" (Republic of Fiji 2018, 5). It has had mainly negative outcomes due to many reasons, among them, a lack of effective community participation, the selection of inappropriate sites, and budget gaps. However, relocation may ultimately be the only option for those communities who risk facing serious climate change adverse effects (Warner and Laczko 2008; Bukvic and Owen 2016; Republic of Fiji 2018). In order to avoid this, several initiatives have set out principles, guidelines, and a toolkit to ensure that planned relocation is implemented in a manner that protects the rights of those who are relocated and those who already reside in the relocation sites. ${ }^{9}$ These documents also include some references to the special circumstances that Indigenous Peoples may face when involved in planned relocation processes. Moreover, they stress the necessity to take into account Indigenous knowledge in decision-making processes related to relocation and to guarantee the exercise of their rights to self-determination, identity, culture, land, and natural resources.

Several Latin American and Caribbean countries have referred to planned relocation as one of their adaptation strategies within their National Communications to the UNFCCC and within their Nationally Determined Contributions (NDCs) to the Paris Agreement (IOM 2019b). For instance, the Guyana Second National Communication to the UNFCCC pointed out that "vast climate change threats will very likely create hardships for the economy and livelihoods of the people of Guyana" requiring "policies for relocation of inhabitants, infrastructure and services that are placed in highly vulnerable areas" (Government of the Guyana 2012, 208). The Belize Third National Communication included evaluating "the feasibility of relocating vulnerable communities" (Government of the Belize National Climate Change Office 2016, 154).

\footnotetext{
${ }^{8}$ For a general overview of the risks of development-induced displacement and resettlement, see Cernea 1995. See also Satiruglu and Choi (2015).

${ }^{9}$ See, e.g., the guidelines developed by the United Nations High Commissioner for Refugees (UNHCR) (Ferris 2012), the guidelines developed by Georgetown University, UNHCR, and Brookings Institution (Ferris 2015) and the toolbox developed by Georgetown, UNHCR, and IOM (Ferris 2016). For a specific country such as Vietnam, see IOM (2017).
} 
Cuba's 2015 National Communication to the UNFCCC mentioned forced relocation as an increasing possibility due to the land loss caused by sea level rise (Government of Cuba 2015) and Cuba's 2020 National Communication included specific mentions to 19 villages that will have to be progressively relocated by 2100 (Government of Cuba 2020).

Similarly, planned relocation is defined as a potential adaptation measure in coastal areas in the Haitian Intended Nationally Determined Contribution (Ministère de l'Environnement de la République d'Haïti 2015). In the list of those actions that should be taken to reduce vulnerability in the social sector for the 2020-2030 decade, the Mexican NDC includes the relocation of "irregular human settlements in zones prone to disasters through land use regulations" (Government of Mexico 2016, 7). In the same vein, the 2017 First NDC of Uruguay includes in its list of main priorities implementation and support needs as well as plans and adaptation measures that address the adverse effects of climate change and the possibility "to have relocated, by 2025 , between 3500 and 6000 of the households in flood or contaminated zones identified through the National Relocation Plan and other national and departmental instruments, enabling access to basic services to relocated population and assigning new uses to give a different significance to flood zones" (Government of Uruguay 2017, 18).

None of these documents make any specific mention to the threats that climate relocation poses for Indigenous Peoples. Only the Panama Third National Communication refers to the social impacts of managed retreat of the Gunayala Indigenous Peoples ${ }^{10}$ and other peoples in similar situations (Government of Panama 2018).

Indeed, in Latin America and the Caribbean, some communities have already taken relocation measures or are considering this possibility. For example, in the Dominican Republic, the community of Boca de Cachón was relocated in 2014. The rising waters of Lake Enriquillo due to high levels of precipitation brought about the resettlement of the affected community a few kilometers away to higher ground. Despite reducing vulnerability and improving access to education and health, the villagers were negatively affected because the new site was far from the road where they would sell their products. In this case, as in many others, this lack of livelihood led to an increased level of vulnerability (Cordero and Lathrop 2014). Similarly, Argentina, Brazil, Colombia,

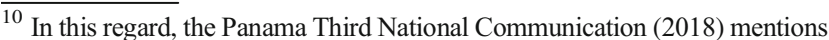
in relation to the Gunayala Indigenous Peoples that "due to the climate trends, it will be necessary to evaluate concrete actions such as, for example, the relocation of the population to mainland in a way that causes the least disturbance to their cosmovision and that is in harmony with the environment" (Government of Panama 2018, 32). It should be taken into account that this document was published 8 years after the Gunas already had decided to relocate.
}

and Guatemala also have cases in which preventive relocation has taken place (Correa 2011).

Against this backdrop, in the following sections, we analyze two cases of managed retreat in which Indigenous Peoples were and are still involved: the case of Gunayala in Panama and the case of the densely Indigenous-inhabited state of Chiapas in Mexico. First, we focus on how the impacts of climate change and other factors have affected these peoples. Second, we explore how the relocation process was initiated and what it eventually implied for these peoples.

\section{From self to managed retreat: the Gunayala case}

Gunayala is one of the comarcas where the Guna people live in Panama. Gunayala is a semiautonomous region where Guna people practice traditional ways of self-government in decision-making processes. It is worth noting that their "political autonomy, their own congress and being a matrilineal society, differentiate the Kuna from other indigenous cultures in Latin America" (Hockamp-Mack 2003, 14). This comarca covers a mountainous forest area on the mainland, more than $400 \mathrm{~km}$ of coastal marine zone, and an archipelago in the northeast of Panama at the Caribbean coast (Hockamp-Mack 2003). The archipelago comprises more than 300 small lowlying coral islands, mangrove forest, and coral reefs (Perafán and Pabón 2018).

\section{The impacts of climate change in Gunayala}

The impacts of climate change are increasingly affecting many regions of the world. However, the Caribbean is considered to be on the frontline: coastal communities, and lowlying archipelagos are progressively exposed to coastal hazards and sea level rise (GIZ 2019). As the Government of Panama recognized in its Second and Third National Communication to the UNFCCC, the impacts of climate change, as well as the population growth, resources' overexploitation, unequal distribution of wealth, and limited infrastructures, are adversely affecting the country (Government of Panama 2011, 2018).

Small island Indigenous Peoples in the Caribbean, such as the Gunas, are particularly vulnerable to the impacts of climate change because of both the coastal location of their settlements and their lifestyles (GIZ 2019). Coastal erosion, floods, increased salinity of drinking water due to (more) intense storms and cyclones, reduction of agricultural land area and its less habitable conditions, disrupted fisheries, and diminished food security have been adversely affecting the livelihoods and cultures of the Guna people since the early 2000s (Hockamp-Mack 2003). Since 1910, the mean sea level has risen more than $15 \mathrm{~cm}$. In addition, there has been surface 
growth of inhabited islands and a dramatic decrease of live hard coral. The surface of the islands has increased as a result of the "unecological" practice of coral infilling which, instead of safeguarding the islands, has exacerbated its exposure to storms and strong currents Guzmán et al. (2003).

Guna people have lived in this comarca since the midnineteenth century, but the impacts of climate change, together with other migration drivers such as overpopulation, poor management of solid waste, water scarcity, health risks (mainly mosquito-related diseases), and drug trafficking are overwhelming factors that are pushing them back to the mainland and therefore threatening their current way of life (Martínez 2013; Perafán and Pabón 2018).

\section{The relocation process}

Guna people have been struggling with the consequences of sea level rise and other environmental stressors since the late nineteenth century. The worst disaster ever registered in Gunayala was a tsunami that took place in 1882. It is estimated that the waves reached $3 \mathrm{~m}$ in height and more than 100 Gunas died (Displacement Solutions 2014). One of the worst storms and flooding events in recent memory took place in 2008, when the encroaching seas, combined with 2 weeks of unusually high tides and storm surges, flooded most of the islands, ruining homes, schools, and subsistence crops (Merry-López 2008; Displacement Solutions 2014). According to two journalists who visited the archipelago: "that tempest remains vivid in the collective memory of the more than 30,000 inhabitants of Guna Yala (...). For two weeks, most homes remained flooded" Leite and Almeida (2018).

In 2010, the community on Gardi Sugdub (Crab Island), one of the most densely populated islands (which stands only $50 \mathrm{~cm}$ above the sea level), decided to relocate to the mainland and created their own commission to organize the relocation process called Comisión de la Barriada (Commission of Barriada). The 2000 inhabitants of Gardi Sugdub planned to move to coastal areas within the Guna's autonomous territory on the mainland. The initial plan was to build the new settlements near a school that was under construction by the Panamanian government with funding from the InterAmerican Development Bank and that was originally planned to be built by 2014 (Displacement Solutions 2016).

The community started to clear the forest in April 2010. They also initiated a dialogue with the government. The Guna people asked for help for the construction of 300 houses. In 2014, 300 families had listed to be resettled in the mainland. Out of them, 200 were then living in Gardi Sugdub and another 100 in Panama City (Displacement Solutions 2014). In 2015, the Ministry of Housing offered them a project, which included the construction of both single and community houses, as well as new roads. However, the design of the houses was not according to Guna's culture (Displacement Solutions 2014, 2016). ${ }^{11}$

The relocation process created some tensions among the Gunas at several levels (Oliver-Smith and Hoffman 2020). At the organizational level, the Guna General Congress (the highest political and administrative decision-making body of the region) and the local congress had differing views regarding the criteria for handling the relocation process (Displacement Solutions 2014). At the community level, intra-community conflicts had surfaced among individuals of the Gardi Sugdub people. These conflicts arose because the original plan included the building of only 65 houses, and individuals had differing views on how to decide who would relocate first. In addition, some tension had also surfaced with regard to (1) those who lived in Panama City and whether they should also have a place in the new village; (2) the varied relocation paces by the different involved actors; (3) the need for a due plan or not; and other factors (Displacement Solutions 2014; Perafán and Pabón 2018).

In 2016, Displacement Solutions also pointed out that "the government has not yet engaged in a participatory planning process with the Gardi Sugdub community on the relocation, nor have any official steps been taken to plan for or address climate displacement in the region" (Displacement Solutions 2016, 2).

Notwithstanding Panama's initial promises, the Government of Panama adopted no official strategy to implement the relocation of the Guna people from Gardi Sugdub. As is happening in other regions of the world, the people themselves assumed the responsibility to carry out the retreat.

In 2017, the Panamanian Ministry of Housing and Territorial Planning (MIVIOT) launched a tender to build a new village called Nuevo Cartí. The MIVIOT awarded the project to a construction company, but it did not assign any budget for it (MIVIOT 2019). By the end of 2018, no house had been built, and the initial amount of money that was promised was used to carry out other infrastructural projects in other parts of Panama Leite and Almeida (2018). At that time, there was considerable uncertainty about the future of the Nuevo Carti new village (Oliver-Smith and Hoffman 2020).

Surprisingly, some new advances were taken by the Government of Panama in 2019. The MIVIOT finally awarded the work of the construction of the new village Nuevo Carti to the construction company HOS S.A. The company carried out the Environmental Impact Assessment, and it announced that the work would start in 2019 MIVIOT (2019).

\footnotetext{
${ }^{11}$ It is worth noting that since 2014, the Displacement Solution association has been following the situation of the Guna people and providing training and support in their relocation process (Displacement Solutions 2016). This association also tried to implement the 2013 Peninsula Principles on Climate Displacement within states in the Gunayala relocation case (Displacement Solutions 2014).
} 
The abovementioned school and the health center (that were originally planned to be ready by 2014) were still under construction, and they were not in use because the relocation of the community had not taken place yet (Displacement Solutions 2019).

In March 2020, ten years after the inhabitants of Gardi Sugdub made the decision to retreat, meetings among the traditional Guna authorities and the Panamanian government took place to agree on, coordinate, and define the methodology and next steps for the relocation of the families from Gardi Sugdub to the housing project on the mainland (MIVIOT 2020). As a result, it is quite inspiring to see the Comisión de la Barriada promoting through its social media the advances in the construction of the new village that are finally taking place (Comisión de la Barriada 2020). However, COVID-19 created yet another barrier to achieve the islanders' objectives, and the construction work (which was at $9.5 \%$ of its overall progress) had been temporary suspended beginning in April 2020 (Government of Panama 2020). Through information provided by the Comisión de la Barriada, the suspension has been lifted and the construction works have begun again (Comisión de la Barriada 2020).

\section{Managed retreat in Mexico: the case of Chiapas after Hurricane Stan}

Mexico is located in another of the world regions more exposed than others to climate change and its adverse effects, including droughts (especially in the North East), floods (in the southern states), and other extreme weather events on both coastlines. This position is further exacerbated by the country's high poverty rate, wide socioeconomic inequalities, and other development issues (Eslava Morales et al. 2006; Saldaña-Zorrilla 2007; Martínez-Velasco et al. 2016; DíazLeal 2017). Although Mexico is the fourth state in the world in terms of biodiversity, it is the second with regard to deforestation (Díaz-Leal 2017). In particular, the southern states such as Chiapas have been heavily hit by climate changerelated extreme events such as hurricanes Mitch in 1998, Emily in 2004, and Stan in 2005 (Martínez-Velasco et al. 2016; Saldaña-Zorrilla 2007). At the same time, Chiapas has the highest poverty rate of the whole country at $76.2 \%$ (CNDH 2016, 57). More than 65\% of its population lives in rural areas, and almost $43 \%$ of employment is related to farming activities (Martínez-Velasco et al. 2016). This socioeconomic position exposes Chiapas and its population even more to climate change-related hazards (Saldaña-Zorrilla 2007). Although Chiapas has abundant forest and water resources, their management is far from efficient. This mismanagement has caused both environmental (especially, forest) degradation and inefficient water sanitation and sewerage systems. Other adverse effects of climate change such as soil erosion and biodiversity losses have further aggravated the land degradation. In addition, urban planning, both in the urban and rural settings, has been extremely chaotic and not carefully planned (Martínez-Velasco et al. 2016).

At the same time, Mexico is home to at least 68 Indigenous Peoples, which represent $21.5 \%$ of the total population. Around $70 \%$ of Indigenous Peoples live in poverty and another $30 \%$ in extreme poverty. They also register low education and employment rates (Del Val et al. 2020). In accordance with Art. 13 of the Decree of the State of Chiapas No. 191 of 1999, there are nine Indigenous Peoples living in Chiapas (in alphabetical order: Chol, Kakchiquel, Lacandon, Mame, Mocho, Tojolabal, Tseltal, Tsotsil, and Zoque), and they represent the majority of the population (Zapata Martí 2006; Santiago Lastra et al., 2016; Tomaselli 2016).

\section{The devastating effects of Hurricane Stan in 2005}

In October 2005, Hurricane Stan heavily hit the southern part of Mexico. From its fourth day, the hurricane was classified as a Category 1 with winds from 130 to $155 \mathrm{~km}$ per hour (Escobedo D'Anglés 2015). However, its derived effects were even more devastating (Saldaña-Zorrilla 2007). In comparison with Wilma, a hurricane that caused destruction in Quintana Roo in 2004, Stan not only caused a more significant amount of damage Gobierno de México (2020) but also affected the poorest, mainly Indigenous, people who, due to their socioeconomic conditions, had a lower coping and adaptive capacity than the Cancun's luxury hotel owners who were hit by Wilma (Zapata Martí 2006; Saldaña-Zorrilla 2007). Chiapas' environment, as mentioned above, was already rather degraded, and its peoples were already suffering from the consequences of the internal Zapatist conflict and inadequate infrastructures, especially with regard to water provision and sanitation (Díaz-Leal 2017). Hurricane Stan has been described as the worst climate-related disaster ever suffered by Chiapas and one of the most significant extreme events of the whole of Mexico (Eslava Morales et al. 2006; Martínez-Velasco et al. 2016; Gobierno de México, 2020).

This hurricane's derived effects eventually caused the saturation of riverbeds and thus the flooding of 98 rivers and violent mudslides in 800 localities of Chiapas (SaldañaZorrilla 2007; Escobedo D'Anglés 2015). The flooding and mudslides further caused the destruction of houses (up to 50,000 ), schools (111 only in Chiapas), sewage systems, health centers, roads, bridges, and other rural and urban infrastructures (Escobedo D'Anglés 2015; Martínez-Velasco et al. 2016; Díaz-Leal 2017). Moreover, the hurricane killed 98 people (86 in Chiapas) and caused more than 2000 million dollars in damage (Saldaña-Zorrilla 2007; Díaz-Leal 2017). The municipalities that were more affected were those that were already in precarious and vulnerable situations and registered a high rate of marginalization (Eslava Morales et al. 
2006; CENAPRED, 2006). The agricultural sector suffered from huge losses since a number of small- and large-scale plantations (especially of coffee), crops (mainly of corn, rice, and bananas), and livestock were destroyed (Saldaña-Zorrilla 2007; Díaz-Leal 2017). Approximately 92,000 people were evacuated from their villages (Escobedo D'Anglés 2015; Díaz-Leal 2017). Those that had to flee first stayed in improvised accommodations in schools, auditoriums, or other public buildings. They were then relocated to other localities that were as far as $150 \mathrm{~km}$ away from the affected villages (Martínez-Velasco et al. 2016).

\section{The relocation process}

The abovementioned 92,000 displaced people were temporarily settled into 492 provisional accommodations in 41 municipalities of Chiapas. The people stayed in these lodgings anywhere from 15 days to 6 months (Díaz-Leal 2017).

Once the roads were accessible again, the displaced people had to choose to either move to another provisional accommodation or be relocated in a new but definitive settlement. In both cases, they received no funding for their transportation and had to provide for themselves (Martínez-Velasco et al. 2016). Officially, all of the people who had suffered damage had to be provided with a housing certificate (certificado de vivienda) that provided the resources to either rebuild their houses or be relocated. However, the majority of people never received this certificate and thus never received financial support (Díaz-Leal 2017). Indeed, the overall relocation process was not properly planned, and it took place with no interinstitutional coordination, no proper participation processes (on the part of the municipal authorities), and no prior environmental impact assessment. This was partly due to the massive devastating effects of the hurricane and the geographic dispersion of the villages as well as other factors such as corruption (Martínez-Velasco et al. 2016; Díaz-Leal 2017). However, the relocation process took too many months and showed a lack of relocation planning and policies both at state (Chiapas) and federal level CENAPRED (2006).

For instance, in the case of the municipality of Motozintla, many displaced people decided to relocate to the municipality of Frontera Comalapa, but they criticized the overall process of relocation, stating it was unclear and chaotic with no clear identification of the beneficiaries. Some beneficiaries and civil servants also used corrupt means (Martínez-Velasco et al. 2016). In 2016, the two new villages of San José Montenegro and Rincón Caballar created in the abovementioned municipality of Frontera Comalapa still had no water provision, severe water sanitation problems (and correlated infections), high levels of water and land pollution, no health center, and only one primary school, implying that pupils who aspired to pursue their education had to move to other municipalities. However, the public transportation was both irregular and more costly. Hence, the costs for drinkable water and transportation were an additional burden for the relocated people, who were not provided with any state financial support. Many people resorted to further migrate to look for employment opportunities. In sum, in this case, the relocation process profoundly transformed the socioeconomic conditions (that were already compromised) and the way of life of the (mainly, Indigenous) displaced people (Martínez-Velasco et al. 2016).

In another case, that of Nueva Colombia, an area with abundant coffee plantations before the hurricane, the people were at least able to participate in an assembly to decide whether to be relocated to the new settlement (Ciudad Rural Sustentable del Café). The people, however, disagreed, and the community was divided between those who saw the relocation as an opportunity and those who preferred to stay to rebuild the coffee plantations (Escobedo D'Anglés 2015). Those who wished to remain were both plantation owners and those employed by them. Notwithstanding the devastating effects of the hurricane and relocation promises, even the people belonging to the poorer sector expressed their willingness to remain to recover their local economy (Escobedo D'Anglés 2015). However, both those who relocated and those who remained had to face several issues. In mid-2012, the relocated people were still living in unhealthy provisional accommodations and waiting for the promised houses of the new settlement of Ciudad Rural Sustentable del Café. Those who stayed in Nueva Colombia suffered from reduced federal financial support regarding both schools and health services and had to self-organize (Escobedo D'Anglés 2015).

In other cases, the displaced people had to wait 2 to 4 years to relocate, and once they did, the quality of their houses was very poor (some did not have electricity, while others had water leaking or other structural problems), and the water quality was very low, which led to some cases of typhus fever. Another adverse effect of the relocations was the de facto denial of participation in the 2006 local elections in Chiapas due to persistent damages to bridges and other infrastructures (Díaz-Leal 2017).

Fourteen years after Hurricane Stan, many people who suffered damage had yet to completely recover from their losses, and the new villages were far from fully working (Notinúcleo Networks 2019).

\section{Discussion: managed retreat as a tool or a threat?}

Despite that Gunayala is extremely affected by climate change and the relocation process of the Guna people of Gardi Sugdub has already started, their case has not received enough 
attention in national and international political spheres. ${ }^{12}$ It took nearly 10 years for the construction work of the new village to start. During this long period, the community faced many unpleasant situations and conflicts, both intra- and intercommunities and with the Panamanian government. It is uncertain when the new village will be finished or how the relocation will be truly implemented. However, past experiences show that resettlement is not just about the construction of infrastructure but also about place attachment, livelihoods, cultural integrity, human rights, and a sense of belonging.

The Guna people's case demonstrates that the impacts of climate change, together with other social and environmental stressors, are so severe that relocation has been ultimately chosen as the only long-term adaptation strategy that can protect this sector of the population. It also shows that planned relocation or managed retreat may lead to the disruption of traditional livelihoods (e.g., traditional fishing) and, if not managed properly, trigger general discontent, fuel social tensions, and ultimately provoke other negative outcomes such as exacerbating environmental degradation in destination areas.

It is estimated that nearly 28,000 Guna peoples will eventually have to relocate from the archipelago to the mainland in the years to come (Oliver-Smith and Hoffman 2020). According to Displacement Solutions (2016), increasing numbers of island communities are being forced to consider relocating to the mainland. It is important that the lessons learned from the still unfinished relocation process from Gardi Sugdub serve as a departure point for future managed retreat.

In the case of Chiapas, as mentioned above, the relocation process was not only improvised but also characterized by a lack of participation, a top-down approach, no previous study on the quality of the land and the level of environmental security of the new settlements, and no supervision of the construction of the new villages. In addition, the necessities of the displaced people were not taken into consideration, and the overall process was not foreseen as a potential project of integral communitarian development by foreseeing, for example, the rehabilitation of families and vocational or other job opportunities; the implementation of a plan or project for capacity building; or the creation of adequate education, health, or other public services (e.g., electric energy provision or paving of roads). Also, the relocations ultimately disrupted the social connections among the affected communities and did not take into consideration any gender-specific measure or the cultural (rural) way of life of the relocated people, who were assigned

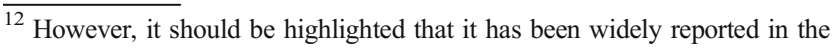
national and international media. For example, "The island people with a climate change escape plan" (Pressy 2017); "Panama Destructive tidal surges and human overpopulation are forcing Panama's indigenous peoples to abandon their islands" Leite and Almeida (2018); "Guna Yala y el cambio climático, tiempos de oportunidad para los indígenas" (Valiente 2019); and "La isla Cangrejo tiene los días contados" (Fariza 2019), among others.
}

urban-type houses and no space for small farming or cattle. All in all, the relocations were far from comprehensive; were eventually done in a violent, rushed way; and were permeated by corruption. In addition, the lack of planning of the relocation processes obliged the displaced people to face a new, difficult challenge without cultural or financial support (Martínez-Velasco et al. 2016; Díaz-Leal 2017). Last, but not least, the level of social cohesion and the specific cultural features of the affected Indigenous peoples were completely ignored. Local, collective aspects of the people with regard to, for example, land or the social, multicultural interrelations; the role of traditional authorities and spiritual leaders; more culturally adapted housing; and keeping orphans with their Indigenous kin people were all measures that should have been taken into consideration but were ultimately totally ignored (Zapata Martí 2006).

\section{Concluding remarks and policy recommendations}

This analysis has explored whether climate-induced planned relocation represents a tool or a threat for Indigenous Peoples in the context of Latin America and the Caribbean. It has first provided a brief overview on both how planned relocation is foreseen in several Latin American countries as a potential tool for climate adaptation and the potential effect on the Indigenous Peoples living on this subcontinent. It has thus focused on two concrete case studies of planned relocations, namely that of the low-lying Caribbean islands of Gunayala inhabited by the Indigenous Guna people in Panama and that of the (mainly) Indigenous-inhabited state of Chiapas after Hurricane Stan in 2005. In both cases, the relocation processes were poorly planned and implemented, and uncertainty and disorganization still reign in both contexts. More importantly, the cultural and socioeconomic consequences of the relocation processes have been severe and can be seen in: intra- and inter-community conflicts or divisions, the disruption of cultural ties, and issues in the employment sector. In particular, in some cases in Chiapas, the gravity of the living conditions of the relocated people in the new settlements caused the migration of many people (Martínez-Velasco et al. 2016). This is a paradox since planned relocations should provide displaced people with new opportunities and not eventually force them to resort to (another environmentally induced) migration. This further implies additional social and cultural losses due to communities' and families' dismemberments.

In sum, planned relocation or managed retreat currently appear to be a threat rather than a tool for Indigenous Peoples (as well as others), at least in the context of Latin America and the Caribbean. This does not imply that the instrument per se is inadequate, but it does make evident that planned relocation absolutely requires efficient planning and 
especially a legitimate and accountable implementation. This will certainly be the main challenge for future potential planned relocation on this subcontinent.

In this sense, policy makers should learn from the negative outcomes of the two cases that we have reported in this policy analysis as well as from other experiences of climate relocation that have involved Indigenous Peoples, such as the case of Indigenous Alaskans and many other communities throughout the Pacific. ${ }^{13}$

In conclusion, the Gunayala and Chiapas cases provide relevant examples of climate-induced managed retreat and offer some lessons that can inform decisions and policies on managed retreat, especially of Indigenous Peoples in Latin America that may be subject to relocation in the future. Thus, a number of policy recommendations stem: (1) prevention and proper preemptive planning are indispensable steps before the relocation takes place; (2) there is a clear need for forward-looking polices on managed retreat, especially in those states or areas that are particularly vulnerable to extreme climate events; (3) the role of the local authorities as well as of traditional authorities (and/or spiritual leaders) should be central at any stage of the relocation process; (4) the affected communities shall have the right to directly participate and contribute to the design of the relocation process. In particular, once a community has been duly informed and has freely taken the decision of relocating, prompt, effective, and community-centered measures should be discussed and decided upon together with the affected community and duly taken and implemented by the competent authorities; (5) proper consultation with the involved peoples is essential for any relocation process but especially in those cases that involve Indigenous Peoples as required by the international law standards on Indigenous rights ${ }^{14}$; (6) not only those who are moving but also the receiving communities should be properly consulted; (7) both economic and non-economic loss and damage, such as the abovementioned sociocultural impacts, should be duly taken into consideration; (8) the competent authorities should elaborate gender-specific measures. (9) The competent authorities should promote the elaboration and the adoption of a communitarian development plan that includes, for instance, the development of new labor skills and capacity building; vocational and job opportunities, social,

\footnotetext{
${ }^{13}$ See, e.g., Koppel Maldonado et al. 2013; April et al., 2016; Albert et al. 2018; Tabe, 2019.

${ }^{14}$ See, e.g., articles $6,15.2,16.2,17.2,22.3,27.3$ and 28.1 of the ILO C169; articles $10,11,19,28,29.2,30.2,32.2,36.2$, and 38 of the UNDRIP; and articles 13.2, 18, 20.4, 23.2, 28.3, and 29.4 of the American Declaration on the Rights of Indigenous Peoples. In particular, both the ILO C169 and the UNDRIP prohibit the relocation of Indigenous Peoples without their free, prior, and informed consent (arts. 16.2 and 10, respectively). With regard to case law, along with a flourishing domestic and international jurisprudence, two pivotal decisions of the Inter-American Court of Human Rights remain particularly essential, namely Saramaka People v. Suriname of 2007 and Kichwa Indigenous People of Sarayaku v. Ecuador of 2012. See further in Tomaselli (2017b, 2020).
}

cultural, and educational activities; and other initiatives to be discussed and decided upon together with the relocated community by ensuring their direct participation and involvement. (10) Once an affected community has relocated, there should be a transparent and accountable monitoring system and a correspondent body that supervises and reports upon the different stages of relocation process and to which the affected people may file a complaint and ask for redress.

\section{Availability of data and materials Not applicable}

Code availability Not applicable

Author contribution In collaborating on this article, the "Climate-induced managed retreat in Latin America and the Caribbean" and "From self to managed retreat: the Gunayala case" sections (and subsections) were written by Beatriz Felipe-Pérez; the "Indigenous Peoples in Latin America and the Caribbean" and "Managed retreat in Mexico: the case of Chiapas after Hurricane Stan" sections (and subsections) were written by Alexandra Tomaselli; and the "Introduction," "Methodology," "Discussion: managed retreat as a tool or a threat?," and "Concluding remarks and policy recommendations" sections were written by both.

\section{Declarations}

Competing interests The authors declare no competing interests.

\section{References}

Ajibade I (2019) Planned retreat in Global South megacities: disentangling policy, practice, and environmental justice. Clim Chang 157:299-317. https://doi.org/10.1007/s10584-019-02535-1

Albert S, Bronen R, Tooler N, Leon J, Yee D, Ash J, Boseto D, Grinham A (2018) Heading for the hills: climate-driven community relocations in the Solomon Islands and Alaska provide insight for a $1.5^{\circ} \mathrm{C}$ future. Reg Environ Chang 18:2261-2272. https://doi.org/10.1007/ s10113-017-1256-8

Alscher S (2011) Environmental degradation and migration on Hispaniola Island. Int Migr 49:164-188. https://doi.org/10.1111/j. 1468-2435.2010.00664.x

Barnett J, Webber M (2010) Accommodating migration to promote adaptation to climate change. World Bank Policy Research Working Paper 5270:1-62. https://doi.org/10.1596/1813-9450-5270

Bukvic A, Owen G (2016) Attitudes towards relocation following Hurricane Sandy: should we stay or should we go? Disasters 14: 101-123. https://doi.org/10.1111/disa.12186

Carey J (2020) Managed retreat increasingly seen as necessary in response to climate change's fury. Proc Natl Acad Sci 117:1318213185. https://doi.org/10.1073/pnas.2008198117

CENAPRED (2006) Centro Nacional de Prevención de Desastres, CEPAL-Comisión Económica para América Latina y el Caribe de las Naciones Unidas Características e impacto socioeconómico de los huracanes "Stan" y "Wilma" en la República Mexicana en el 2005. Ciudad de Mexico. www.cepal.org/es/publicaciones/25801caracteristicas-impacto-socioeconomico-huracanes-stan-wilma-larepublica. Accessed 21 Jan 2021

CEPAL (2018) Comisión Económica para América Latina y el Caribe de las Naciones Unidas 1. Estadísticas sociales, table 1.1.1 Población. 
http://interwp.cepal.org/anuario_estadistico/anuario_2018/index. asp?anuario $=2018 \&$ idioma $=$ sp. Accessed 17 Aug 2020

Cernea M (1995) Understanding and preventing impoverishment risks from displacement: reflections on the state of knowledge. World Bank Reprint Series: Number 478. World Bank Group, Washington

Clark B (2016) El segundo lago más grande de Bolivia se secó ¿Hay salvación?. National Geographic en Español. www.ngenespanol. com/naturaleza/ecosistemas/16/01/26/sequia-lago-bolivia-cambioclimatico-poopo-muerte/. Accessed 3 Aug 2020

CNDH (2016) Informe Especial sobre Desplazamiento Forzado Interno (DFI) en México. Comisión Nacional de los Derechos Humanos, Ciudad de México

Comisión de la Barriada (2020) Memorias del plan de reubicación de la comunidad Cardi Sugdub, proyecto Nuevo Carti. www.facebook. com/Barriadanuevogardisugdub/. Accessed 4 August

Cordero A, Lathrop G (2014) Relaciones entre medio ambiente y migraciones en República Dominicana. Evidencias, interpretaciones y políticas a partir de un estudio de casos. International Organization for Migration, Geneva

Correa E (2011) Reasentamiento preventivo de poblaciones en riesgo de desastre: Experiencias de América Latina. World Bank, Washington

Dannenberg A, Frumkin H, Hess J, Hebi K (2019) Managed retreat as a strategy for climate change adaptation in small communities: public health implications. Clim Chang 153:1-14. https://doi.org/10.1007/ s10584-019-02382-0

Del Popolo F (2017) Los pueblos indígenas en América (Abya Yala): desafíos para la igualdad en la diversidad. Comisión Económica para América Latina y el Caribe (CEPAL), Santiago de Chile

Del Popolo F, Oyarce AM, Schkolnik S, Velasco F (2010) Censos 2010 y la inclusión del enfoque étnico: hacia una construcción participativa con pueblos indígenas y afrodescendientes de América Latina. Comisión Económica para América Latina-CEPAL, Santiago de Chile

Del Val J, Pérez Martínez JM, Sánchez García C, Avendaño Villafuerte E (2020) Mexico. In: Mamo D (ed) The indigenous world 2020. The International Work Group for Indigenous Affairs-IWGIA, Copenhagen, pp 438-445

Díaz-Leal LR (2017) Desplazamiento Ambiental: Experiencia Global, Realidad Mexicana. Tres Picos Servicios Editoriales, Ciudad de México

Displacement Solutions (2019) Lessons learned from post-earthquake policy in Nepal. Guidance for further Housing, Land and Property Disaster and Reconstruction from Law and Policy Reform. Displacement Solutions, Geneva

ECLAC (2015) The economics of climate change in Latin America and the Caribbean. Paradoxes and challenges of sustainable development. Economic Commission for Latin America and the Caribbean, Santiago de Chile

ECLAC (2016) The social inequality matrix in Latin America. Economic Commission for Latin America and the Caribbean, Santiago de Chile. https://repositorio.cepal.org/bitstream/handle/11362/40710/ 1/S1600945 en.pdf. Accessed 21 Jan 2021

Escobedo D'Anglés L (2015) 2005-2010: los efectos acumulados de los huracanes y la reubicación de poblaciones en Chiapas (México). In: Ferradas P (ed) La memoria es también porvenir. Historia mundial de los desastres. Soluciones Prácticas, Lima, pp 362-363

Eslava Morales H, Jiménez Espinosa M, Salas Salinas MA (2006). Características del Huracán "Stan" en Chiapas. In: Secretaria de Gobierno-CENAPRED (eds.) Características e Impacto socioeconómico de los Principales Desastres ocurridos en la República Mexicana en el año 2005. Ciudad de México 308-364

Fariza I (2019) La isla Cangrejo tiene los días contados. El País. https:// elpais.com/sociedad/2019/05/24/actualidad/1558719716_076472. html. Accessed 4 Aug 2020
Ferris E (2012) Protection and planned relocations in the context of climate change. United Nations High Commissioner for Refugees, Geneva

Ferris E (2014) Planned relocation, disasters and climate change: consolidating good practices and preparing for the future. Background Document. SanRemo Consultation. United Nations High Commissioner for Refugees, Brookings, Georgetown University, Geneva

Ferris E (2015) Guidance on protecting people from disasters and environmental change through planned relocation. United Nations High Commissioner for Refugees, Brookings, Georgetown University, Geneva

Ferris E (2016) A toolbox: Planning relocations to protect people from disasters and environmental change. United Nations High Commissioner for Refugees, Georgetown University, International Organization for Migration, Geneva

Giraudo L, Sánchez JM (2008) Neoindigenismo y movimientos indígenas en América Latina. In: Malamud C, Isbell P, Tejedor C (eds) Anuario Iberoamericano 2008. Ediciones Pirámide, Madrid, pp 63-76

GIZ (2019) Human mobility in the context of climate change. Migration, displacement and planned relocation in the Eastern Caribbean, the Pacific and the Philippines. Deutsche Gesellschaft für Internationale Zusammenarbeit-GIZ, Bonn, Eschborn

Gobierno de México (2020) A 15 años de los huracanes Stan y Wilma. https://www.gob.mx/cenapred/es/articulos/a-quince-anos-de-loshuracanes-stan-y-wilma?idiom=es. Accessed 21 Jan 2021

González C (2015) Environmental justice, human rights, and the Global South. Santa Clara Journal of International Law 13:151-195 http:// digitalcommons.law.scu.edu/scujil/vol13/iss 1/8

González C (2021) Racial capitalism, climate justice, and climate displacement. Oñati Socio-Legal Series, Symposium on Climate Justice in the Anthropocene 11:108-147. https://ssrn.com/ abstract $=3626490$

Government of Cuba (2015) Segunda Comunicación Nacional a la Convención Marco de las Naciones Unidas sobre Cambio Climático. https://unfccc.int/sites/default/files/resource/cubnc2.pdf. Accessed 1 Aug 2020

Government of Cuba (2020) Tercera Comunicación Nacional a la Convención Marco de las Naciones Unidas sobre Cambio Climático. https://unfccc.int/sites/default/files/resource/Third\% 20National\%20Communication.\%20Cuba.pdf . Accessed 28 Jan 2021

Government of Mexico (2016) Intended Nationally Determined Contribution. www4.unfccc.int/sites/ndcstaging/ PublishedDocuments/Mexico\%20First/MEXICO\%20INDC\% 2003.30.2015.pdf. Accessed 28 Jan 2021

Government of Panama (2011) Segunda Comunicación Nacional ante la Convención Marco de las Naciones Unidas sobre el Cambio Climático. https://unfccc.int/resource/docs/natc/pannc2.pdf

Government of Panama (2018) Tercera Comunicación Nacional ante la Convención Marco de las Naciones Unidas sobre el Cambio Climático. https://unfccc.int/sites/default/files/resource/Tercera\% 20Comunicacion\%20Naciona1\%20Panama.pdf . Accessed 1 Aug 2020

Government of Panama (2020) Decreto Ejecutivo N ${ }^{\circ} 506$ (De martes 24 de marzo de 2020) que ordena la suspensión temporal de la actividad de la industria de la construcción. www.gacetaoficial.gob.pa/ pdfTemp/28987_A/GacetaNo_28987a_20200324.pdf. Accessed 1 Aug 2020

Government of the Belize National Climate Change Office (2016) Third National Communication to the United Nations Framework Convention on Climate Change. https://unfccc.int/sites/default/ files/resource/blznc3.pdf. Accessed 1 Aug 2020

Government of the Guyana (2012) Second National Communication to the United Nations Framework Convention on Climate Change. 
https://unfccc.int/sites/default/files/resource/guync2.pdf. Accessed 1 Aug 2020

Government of Uruguay (2017) First Nationally Determined Contribution to the Paris Agreement (Unofficial translation). www4.unfecc.int/sites/ndcstaging/PublishedDocuments/Uruguay\% 20 First/Uruguay_First $\% 20$ Nationally $\% 20$ Determined $\%$ 20Contribution.pdf. Accessed 1 Aug 2020

Guzmán H, Guevara C, Castillo A (2003) Natural disturbances and mining of Panamanian coral reefs by indigenous people. Conserv Biol 17:1396-1401

Hansungule M, Oluborode Jegede A (2014) The impact of indigenous peoples' land tenure and use: the case for a regional policy in Africa. International Journal on Minority and Group Rights 21:256-291. https://doi.org/10.1163/15718115-02102004

Hockamp-Mack S (2003) Biodiversity and tourism. The case for the sustainable use of the marine resources of Kuna Yala, Panama. The Federal Ministry for the Environment, Nature Conservation and Nuclear Safety, Bonn

IDMC (2020) Global Report on Internal Displacement 2020. Internal Displacement Monitoring Centre, Geneva

IOM (2009) Migration, environment and climate change: assessing the evidence. International Organization for Migration, Geneva

IOM (2017) Planned relocation for communities in the context of environmental change and climate change. A training manual for provincial and local authorities. International Organization for Migration, Vietnam

IOM (2019a) Glossary on Migration. International Organization for Migration, Geneva

IOM (2019b) La movilidad humana en la agenda climática de las Américas. International Organization for Migration, San José de Costa Rica

IPCC (2014) Climate Change 2014: Synthesis Report. Contribution of working groups I, II and III to the fifth assessment report of the intergovernmental panel on climate change. Intergovernmental Panel on Climate Change, Geneva

IPCC (2018) Special Report. Global warming of $1,5^{\circ} \mathrm{C}$. Summary for policymakers. Intergovernmental Panel on Climate Change, Geneva

IPCC (2019) Special Report on climate change, desertification, land degradation, sustainable land management, food security, and greenhouse gas fluxes in terrestrial ecosystems. Final Government Distribution. Intergovernmental Panel on Climate Change, Geneva

Koppel Maldonado J, Shearer C, Bronen R, Peterson K, Lazruz H (2013) The impact of climate change on tribal communities in the US: displacement, relocation, and human rights. In: Maldonado JK, Colombi B, Pandya R (eds) Climate Change and Indigenous Peoples in the United States. Springer, Cham. https://doi.org/10. 1007/9783-319-05266-3 8

Leite M, Almeida L (2018) Panama destructive tidal surges and human overpopulation are forcing Panama's indigenous peoples to abandon their islands. https://arte.folha.uol.com.br/ciencia/climate-crisis/ panama/destructive-tidal-surges-and-human-overpopulation-areforcing-panamas-indigenous-peoples-to-abandon-their-islands/. Accessed 28 Jul 2020

Macchi M (2008) Indigenous and traditional peoples and climate change. International Union for Conservation of Nature, Gland

Martínez M (2013) La movilidad Guna (Panamá): habitando bosques, islas y ciudades. Perifèria - Revista de recerca i formació en antropologia 18:59-69

Martínez-Velasco G, Lopez-Ochoa MS, Álvarez-Gordillo G, Schmook B (2016) Desastres, desplazamiento interno y migración laboral en la Sierra de Chiapas. Papeles de Población 87:201-232

McMichael C, Katonivualiku M, Powel T (2019) Planned relocation and everyday agency in low-lying coastal villages in Fiji. Geogr J 185: 325-337. https://doi.org/10.1111/geoj.12312
Merry-López A (2008) Alarma por aumento del nivel del mar. www. geocities.ws/kunayarki/edicion anterior.013.htm. Accessed 28 Jul 2020

Miletto M, Caretta MA, Burchi F, Zanlucchi G (2017) Migration and its interdependencies with water scarcity, gender and youth employment. United Nations Educational, Scientific and Cultural Organization-UNESCO, Paris

Ministère de l'Environnement de la République d'Haïti (2015) Contribution Prévue Déterminée au niveau national. www4. unfccc.int/sites/ndcstaging/PublishedDocuments/Haiti\%20First/ CPDN_Republique\%20d\%27Haiti.pdf. Accessed 30 Jul 2020

Ministerio de Desarrollo Social y Familia (2019) CASEN 2019. Informe Desarrollo Social 2019. Ministerio de Desarrollo Social y Familia, Santiago de Chile

MIVIOT (2019) Miviot participa en reunión interinstitucional sobre proyecto Nuevo Cartí. www.miviot.gob.pa/archivos/32186. Accessed 29 Jul 2020

MIVIOT (2020) Miviot coordina traslado de familias indígenas al proyecto Nuevo Cartí. www.miviot.gob.pa/archivos/35017. Accessed 29 July

Nansen Intitiative (n.d.) The Nansen initiative on disaster-induced crossborder displacement. www.nanseninitiative.org. Accessed 30 Dec 2020

Notinúcleo Networks (2019) 14 años del huracán Stan (Galería). https:// notinucleo.com/estado/huracan-stan. Accessed 19 Aug 2020

Ødegaard CV (2016) Mobility, markets and indigenous socialities: contemporary migration in the Peruvian Andes. Routledge, London

Oliver-Smith A, Hoffman S (2020) The angry earth. Routledge, New York

Perafán C, Pabón M (2018) Traslado de Gardi Sugdub a Tierra Firme. Estudio de Impacto Socio-Cultural. República de Panamá, Ministerio de Gobierno y Justicia, Comarca Gunayala, Banco Interamericano de Desarrollo, Panamá

Pires E, Lyra L, Salles F, Abreu C (2016) Environmental migration in Brazil: current contact and systemic challenges. Migration, Environment and Climate Change: Policy Brief Series 2:1-8

Platform on Disaster Displacement (n.d.) The platform on disaster displacement. https://disasterdisplacement.org. Accessed 30 Dec 2020

Econews Portal (2019) Indigenous leaders assassinated in Colombia. https://ecoterra.info/index.php/en/1413-indigenous-leadersassassinated-in-colombia. Accessed 12 Aug 2020

Pressy L (2017) The island people with a climate change escape plan. BBC News. www.bbc.com/news/magazine-41337815. Accessed 5 Aug 2020

Priotto G (2017) Migraciones, ambiente y cambio climático. Estudios de Caso en América del Sur. International Organization for Migration, Buenos Aires

Republic of Fiji (2018) Planned relocation guidelines. A framework to undertake climate change related relocation. Ministry of Economy of Fiji, Fiji

Robson JP (2019) Indigenous communities, migrant organizations, and the ephemeral nature of translocality. Lat Am Res Rev 54:103-120. https://doi.org/10.25222/larr.152

Saldaña-Zorrilla SO (2007) Socioeconomic vulnerability to natural disasters in Mexico: rural poor, trade and public response. CEPAL Serie Estudios y perspectivas - México 92:1-64

Santiago Lastra JA, Manco JF, Choque Guzmán B, Ramírez Sosa CA, Valencia Barrera E (2016) Modelación de los Efectos del Cambio Climático en la Cuenca Valle de Jovel, Chiapas, México. Caos Conciencia 10:1-12

Sardiza Miranda A, du Parc E, Benet J, Kurkaa M, Fung V (2020) Inclusive data on disaster displacement must include indigenous people. Internal Displacement Monitoring Centre. www.internaldisplacement.org/expert-opinion/inclusive-data-on-disasterdisplacement-must-include-indigenous-people. Accessed 10 Aug 2020 
Satiruglu I, Choi N (2015) Development-induced displacement and resettlement. Routledge, New York and Oxon

Siders AR, Hino M, Mach KJ (2019) The case for strategic and managed climate retreat. Science 365:761-763. https://doi.org/10.1126/ science.aax 8346

Solutions D (2014) Cambio climático y desplazamiento en la región autónoma de Gunayala. Panamá. Informe de misión, Displacement Solutions, Geneva

Solutions D (2016) An overview on the relocation of Guna indigenous communities in Gunayala. Panama. Mission Report, Displacement Solutions, Geneva

Stephens C (2015) The indigenous experience of urbanization. In: State of the World Minorities and Indigenous Peoples 2015. Minority Rights Group International, London, pp 55-61 https:// minorityrights.org/wp-content/uploads/2015/07/MRG-state-of-theworlds-minorities-2015-FULL-TEXT.pdf. Accessed 22 January 2021.

Survival International (2019) Amazon Guardian killed, another shot, as loggers attack in Brazil. www.survivalinternational.org/news/ 12253. Accessed 10 Aug 2020

Tabe T (2019) Climate change migration and displacement: learning from past relocations in the pacific. Soc Sci 8:218-236. https://doi.org/10. 3390/socsci8070218

Thomas A, Benjamin L (2020) Non-economic loss and damage: lessons from displacement in the Caribbean. Clim Pol 20:715-720. https:// doi.org/10.1080/14693062.2019.1640105

Tomaselli A (2016) Exploring indigenous self-governments and forms of autonomies. In: Lennox C, Short D (eds) Handbook of Indigenous Peoples' Rights. Routledge, London, New York, pp 83-100

Tomaselli A (2017a) Indigenous peoples in Europe and their international protection vis-a-vis the threat of climate change. European
Yearbook on Minority Issues 14:37-65. https://doi.org/10.1163/ 2211611701401003

Tomaselli A (2017b) The right to political participation of indigenous peoples: a holistic approach. International Journal on Minority and Group Rights 24:390-427. https://doi.org/10.1163/1571811502404006

Tomaselli A (2020) Political participation, the International Labour Organization, and indigenous peoples: Convention 169 participatory rights. The International Journal of Human Rights 24:127-143. https://doi.org/10.1080/13642987.2019.1677612

UNFCCC (2015) Decision 1/CP.21 Adoption of the Paris Agreement. https://unfccc.int/resource/docs/2015/cop21/eng/10a01.pdf Accessed 4 Aug 2020

Valiente D (2019) Guna Yala y el cambio climático, tiempos de oportunidad para los indígenas. La Estrella de Panamá. www. laestrella.com.pa/cafe-estrella/planeta/190402/guna-yala-cambioclimatico. Accessed 4 Aug 2020

Velasco-Ortiz L (2014) Transnational ethnic processes: indigenous Mexican migrations to the United States. Lat Am Perspect 41:54 74. https://doi.org/10.1177/0094582X14532073

Warner K, Laczko F (2008) Una agenda de investigación global. Revista Migraciones Forzadas 31:59-61

Warner K, Sherbinin A, Chai-Onn T (2009) In search of shelter. Mapping the Effects of Climate Change on Human Migration and Displacement. http://ciesin.columbia.edu/documents/clim-migrreport-june09 final.pdf. Accessed 4 Aug 2020

Zapata Martí R (2006) Los efectos de los desastres en 2004 y 2005: la necesidad de adaptación de largo plazo CEPAL Serie Estudios y perspectivas - México 54:1-47

Publisher's Note Springer Nature remains neutral with regard to jurisdictional claims in published maps and institutional affiliations. 